Photo-physical and Structural Impact of Phosphorylated Anions Associated to Lanthanide Complexes in Water

Loïc J. Chabonnière, ${ }^{* a}$ Rachel Schurhammer, ${ }^{b}$ Samir Mameri, ${ }^{a}$ Georges Wipff, ${ }^{* b}$ and Raymond F. Ziessel ${ }^{* a}$

Supplementary Information (13 pages including this one) 
Full reference 43 : Frisch, M. J.; Trucks, G. W.; Schlegel, H. B.; Scuseria, G. E.; Robb, M. A.; Cheeseman, J. R.; Zakrzewski, V. G.; Montgomery, J. A., Jr.; Stratmann, R. E.; Burant, J. C.; Dapprich, S.; Millam, J. M.; Daniels, A. D.; Kudin, K. N.; Strain, M. C.; Farkas, O.; Tomasi, J.; Barone, V.; Cossi, M.; Cammi, R.; Mennucci, B.; Pomelli, C.; Adamo, C.; Clifford, S.; Ochterski, J.; Petersson, G. A.; Ayala, P. Y.; Cui, Q.; Morokuma, K.; Malick, D. K.; Rabuck, A. D.; Raghavachari, K.; Foresman, J. B.; Cioslowski, J.; Ortiz, J. V.; Stefanov, B. B.; Liu, G.; Liashenko, A.; Piskorz, P.; Komaromi, I.; Gomperts, R.; Martin, R. L.; Fox, D. J.; Keith, T.; Al-Laham, M. A.; Peng, C. Y.; Nanayakkara, A.; Gonzalez, C.; Challacombe, M.; Gill, P. M. W.; Johnson, B.; Chen, W.; Wong, M. W.; Andres, J. L.; Gonzalez, C.; HeadGordon, M.; Replogle, E. S.; Pople, J. A., Gaussian 98; Revision A.5 ed.; Gaussian, Inc.: Pittsburgh PA. 1998.

\section{Synthesis of Ligand $\mathbf{L}_{\mathbf{C}}$.}

Bis-[(6'-carboxy-2,2'-bipyridine-6-yl) $]$ phenylphosphine oxide $\mathbf{L}_{\mathbf{C}}:$ Bis-[(6'-carboethoxy2,2'-bipyridine-6-yl)]phenylphosphine oxide (180 mg, $0.31 \mathrm{mmol})$ and $\mathrm{NaOH}(50 \mathrm{mg}, 1.25$ mmol) were dissolved in a mixture of EtOH $(15 \mathrm{~mL})$ and $\mathrm{H}_{2} \mathrm{O}(10 \mathrm{~mL})$ and heated at $72{ }^{\circ} \mathrm{C}$ during $14 \mathrm{~h}$. After the mixture had cooled to r.t., the solvents were evaporated under reduced pressure. The solid was dissolved in $\mathrm{H}_{2} \mathrm{O}$, precipitated with dil. $\mathrm{HCl}(2 \mathrm{~N})$ and centrifugated to give $\mathbf{L}_{\mathbf{C}} \cdot 2 \mathrm{HCl} \cdot \mathrm{H}_{2} \mathrm{O}(147 \mathrm{mg}, 77 \%)$ as a yellow cristalline solid. ${ }^{1} \mathrm{H}-\mathrm{NMR}\left(300 \mathrm{MHz}, \mathrm{CD}_{3} \mathrm{OD}\right)$ : $\delta=7.59-7.70(\mathrm{~m}, 3 \mathrm{H}), 7.97\left(\mathrm{t}, 2 \mathrm{H},{ }^{3} \mathrm{~J}=8.0 \mathrm{~Hz}\right), 8.13-8.21(\mathrm{~m}, 8 \mathrm{H}), 8.42\left(\mathrm{~d}, 2 \mathrm{H},{ }^{3} \mathrm{~J}=8.0 \mathrm{~Hz}\right)$ 8.79-8.83 (m, 2H); ${ }^{13} \mathrm{C}\left\{{ }^{1} \mathrm{H}\right\}-\mathrm{NMR}\left(75 \mathrm{MHz}, \mathrm{CD}_{3} \mathrm{OD}\right): \delta=124.9(\mathrm{CH}), 125.5(\mathrm{CH}), 126.6$ $(\mathrm{CH}), 129.5\left(\mathrm{CH}, \mathrm{d}, \mathrm{J}_{\mathrm{PC}}=11 \mathrm{~Hz}\right), 129.8(\mathrm{CH}), 130.7\left(\mathrm{C}_{\text {quat. }}, \mathrm{d}, \mathrm{J}_{\mathrm{PC}}=104 \mathrm{~Hz}\right), 133.6(\mathrm{CH}$, $\left.\mathrm{J}_{\mathrm{PC}}=9 \mathrm{~Hz}\right), 134.0(\mathrm{CH}), 139.1\left(\mathrm{CH}, \mathrm{d}, \mathrm{J}_{\mathrm{PC}}=9 \mathrm{~Hz}\right), 139.8(\mathrm{CH}), 149.1\left(\mathrm{C}_{\text {quat. }}\right), 156.4\left(\mathrm{C}_{\text {quat. }}\right)$, 
156.7, 156.8, $157.1\left(2 \mathrm{C}_{\text {quat }}\right), 167.9\left(\mathrm{C}_{\mathrm{C}=\mathrm{O}}\right) ;{ }^{31} \mathrm{P}-\mathrm{NMR}\left(\mathrm{CD}_{3} \mathrm{OD}\right): \delta=21.45 ; \mathrm{IR}\left(\mathrm{KBr}, \mathrm{cm}^{-1}\right)$ : $2922(\mathrm{w}), 1763(\mathrm{w}), 1717\left(\mathrm{~s}, \mathrm{v}_{\mathrm{CO}}\right), 1577\left(\mathrm{~m}, \mathrm{v}_{\mathrm{C}=\mathrm{C}}, \mathrm{v}_{\mathrm{C}=\mathrm{N}}\right), 1557(\mathrm{w}), 1430\left(\mathrm{~s}, \mathrm{v}_{\mathrm{C}=\mathrm{C}}\right), 1379(\mathrm{~m})$, $1353(\mathrm{~m}), 1238\left(\mathrm{~m}, \mathrm{v}_{\mathrm{P}=\mathrm{O}}\right), 1135(\mathrm{~m}), 1103(\mathrm{~m}), 1077(\mathrm{~s}), 766(\mathrm{~s})$; $\mathrm{MS}\left(\mathrm{FAB}^{+}\right): 523.3\left([\mathrm{M}+\mathrm{H}]^{+}\right.$, 100\%); Anal. Calcd for $\mathrm{C}_{28} \mathrm{H}_{19} \mathrm{~N}_{4} \mathrm{PO}_{5} .2 \mathrm{HCl} . \mathrm{H}_{2} \mathrm{O}$ : C 54.83, H 3.78, N 9.13. Found: C 54.64, H $3.65, \mathrm{~N} 8.96$.

$\operatorname{EuL}_{\mathbf{B}}^{+}$

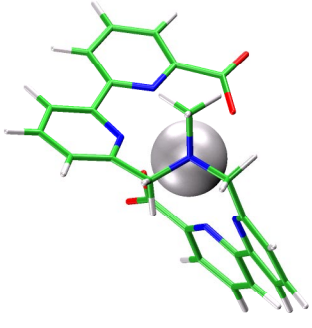

$\mathrm{EuL}_{\mathbf{B}}\left(\mathrm{NO}_{3}\right)$

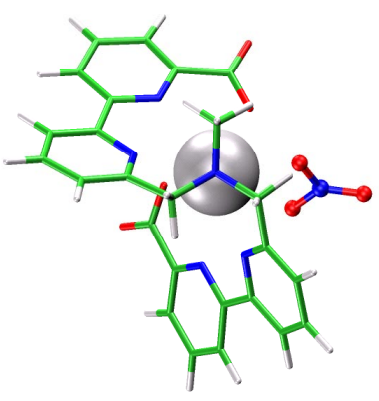

$\mathrm{EuL}_{\mathbf{B}}\left(\mathrm{HPO}_{4}\right)^{-}$
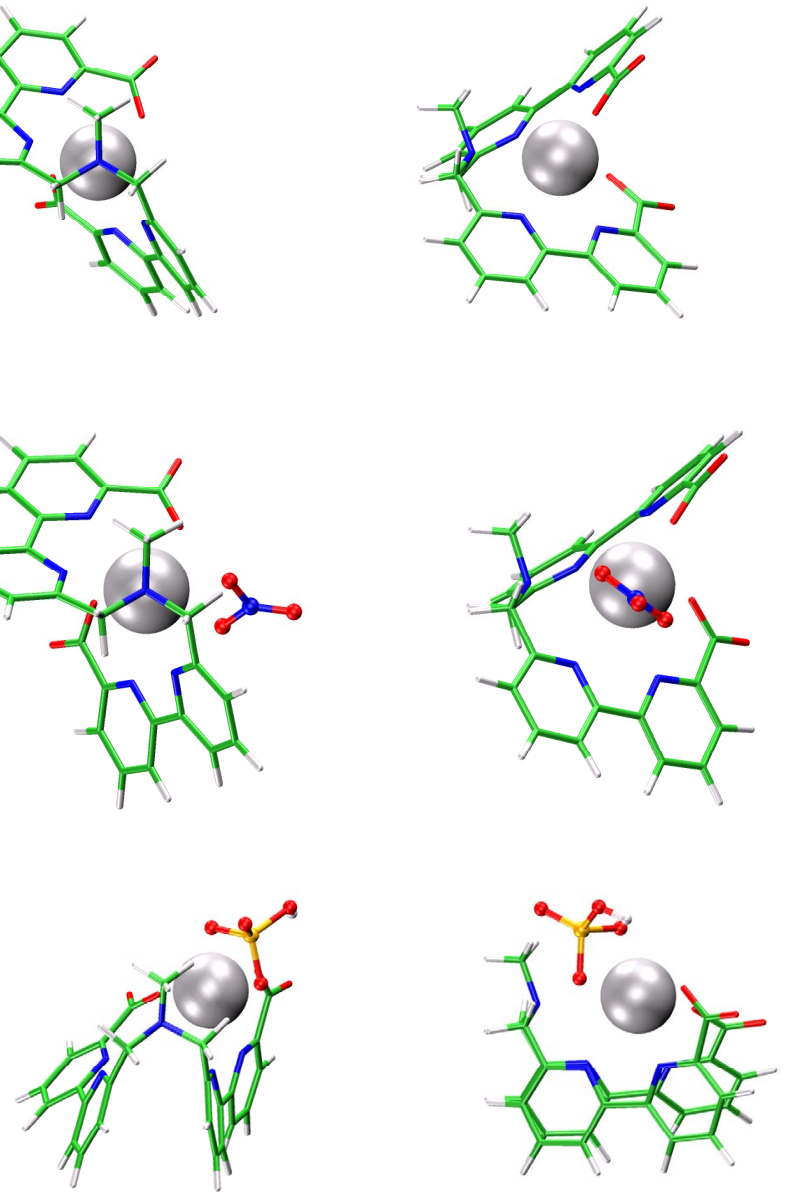

Figure S1 : Orthogonal views of the $\left[\mathrm{EuL}_{\mathbf{B}}\right]^{+}$complex and its adducts with nitrate and $\mathrm{HPO}_{4}{ }^{2-}$ after a B3LYP/6-31G* optimization. 

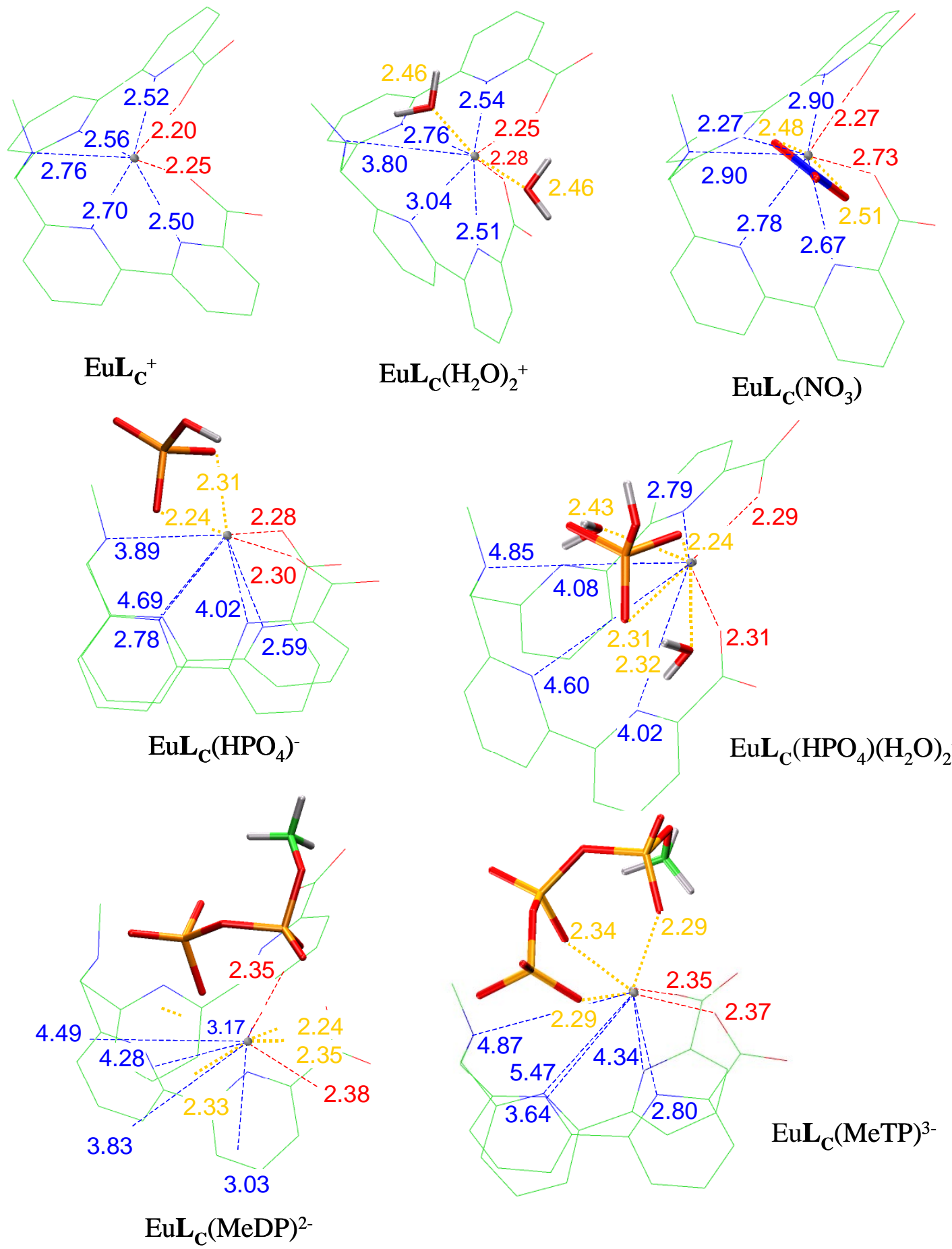

$\mathrm{EuL}_{\mathbf{C}}\left(\mathrm{NO}_{3}\right)$
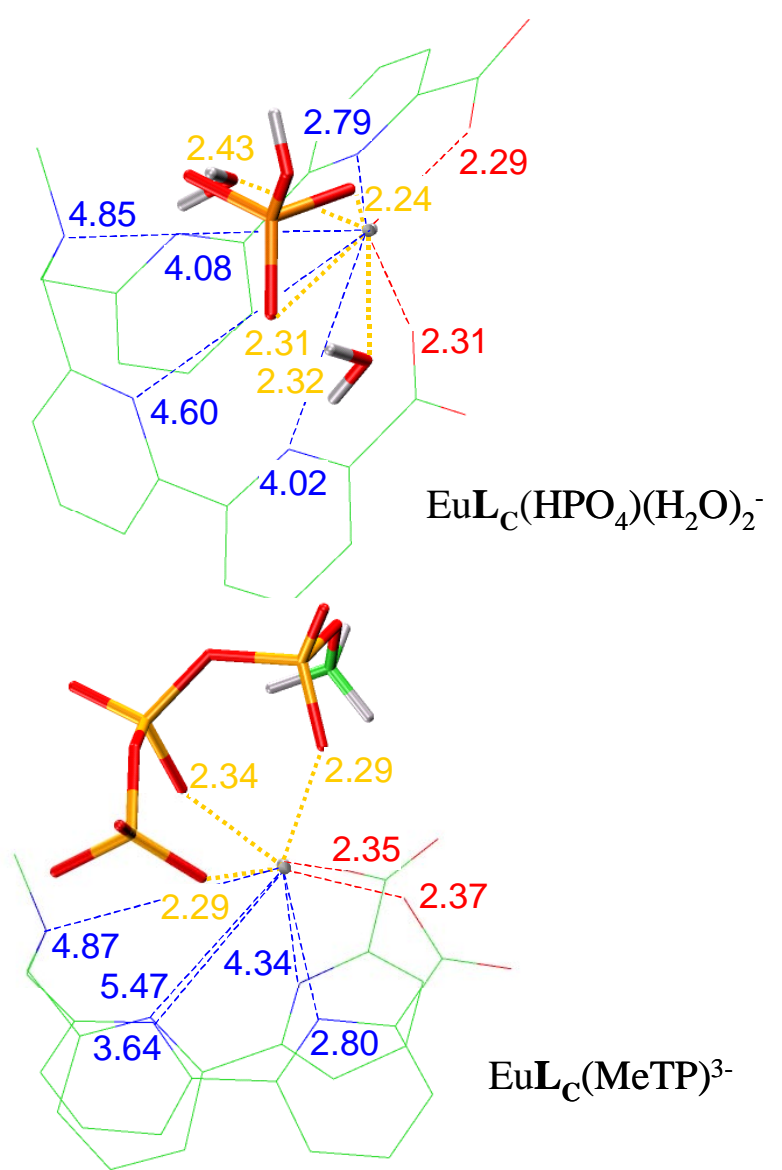

$\mathrm{EuL}_{\mathbf{C}}(\mathrm{MeDP})^{2-}$

Figure S2 : Typical bond distances (in $\AA$ ). 


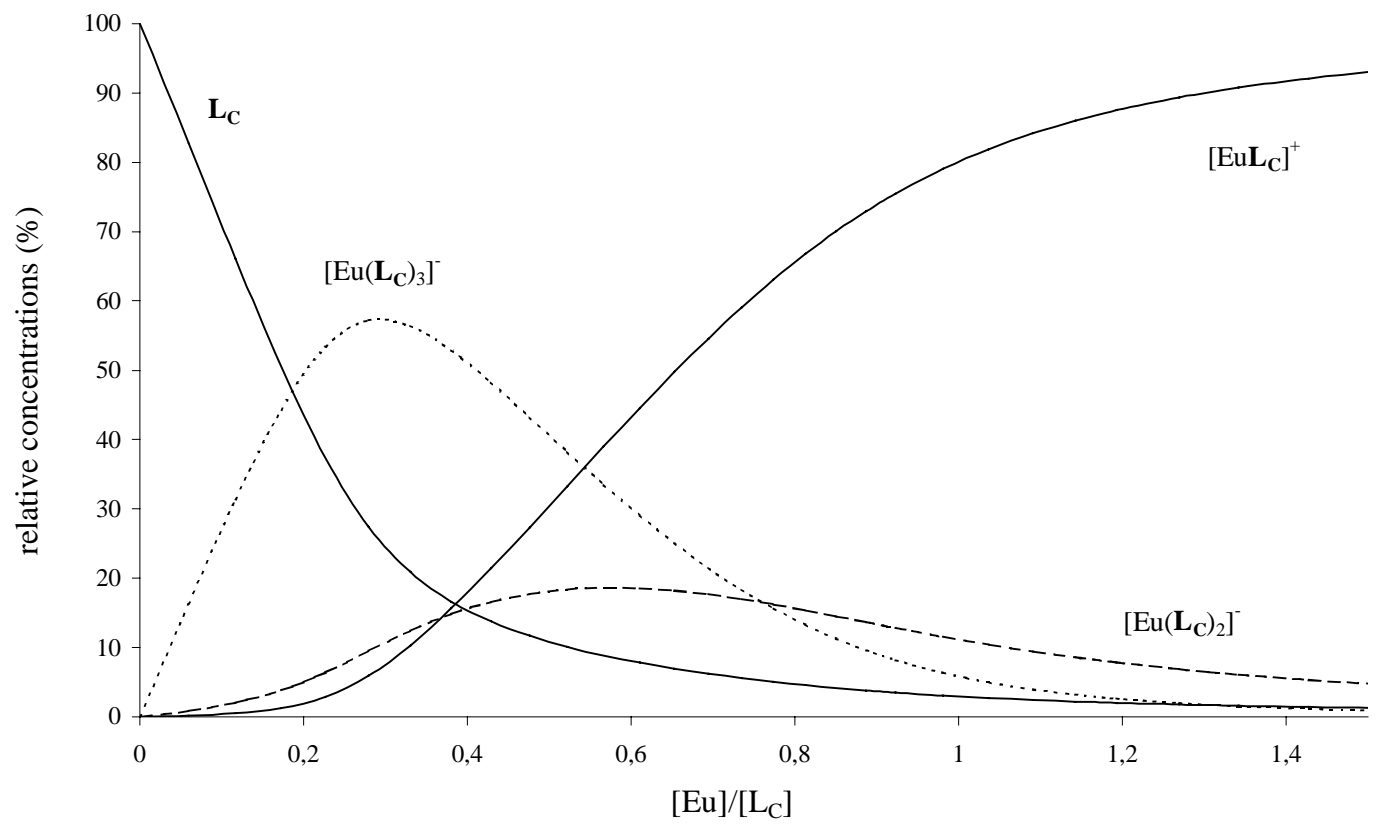

Figure S3 : Evolution of the relative concentrations of the species formed upon titration of $\mathbf{L}_{\mathbf{C}}$ with $\mathrm{EuCl}_{3} \cdot 6 \mathrm{H}_{2} \mathrm{O}$ in water $(0.01 \mathrm{M}$ TRIS/HCl, $\mathrm{pH}=7.0)$.

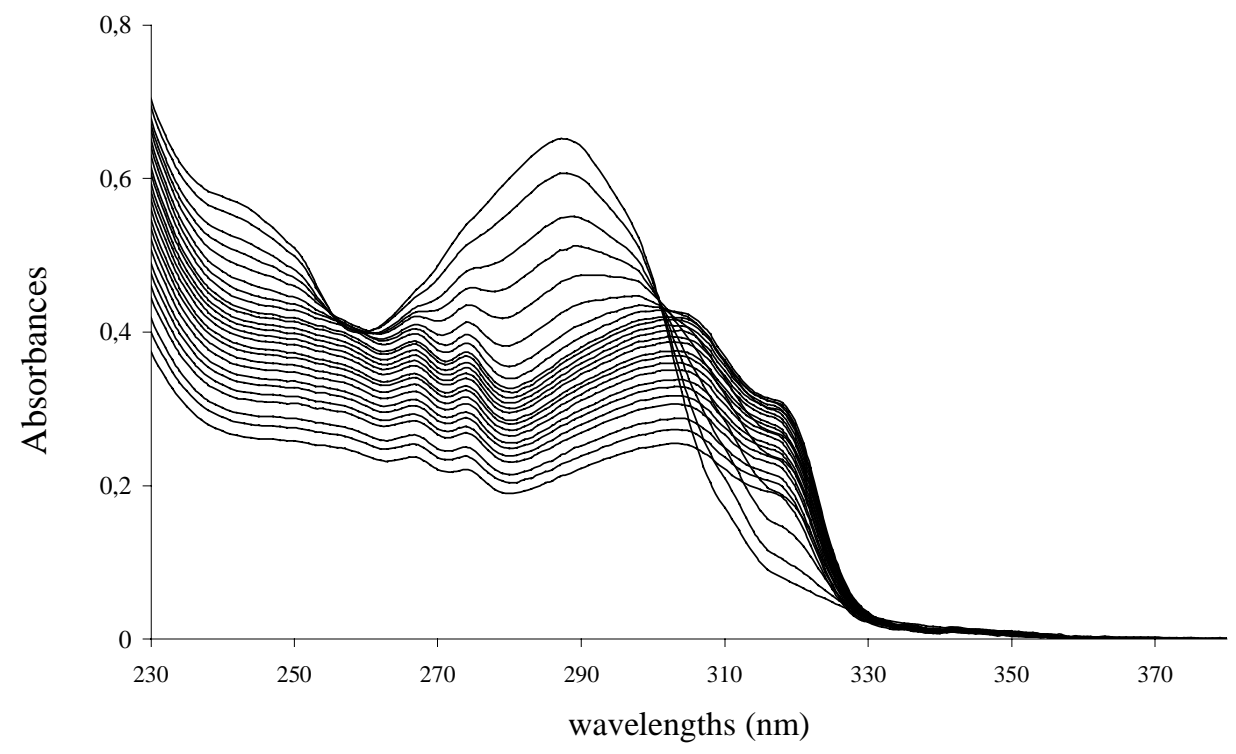

Figure S4 : Evolution of the UV-Vis absorption spectra of a solution of $\mathbf{L}_{\mathbf{C}}$ upon addition of $\mathrm{EuCl}_{3} \cdot 6 \mathrm{H}_{2} \mathrm{O}$ in water, $0.01 \mathrm{M}$ TRIS $/ \mathrm{HClO}_{4}, \mathrm{pH}=7.0$ (uncorrected for dilution). 


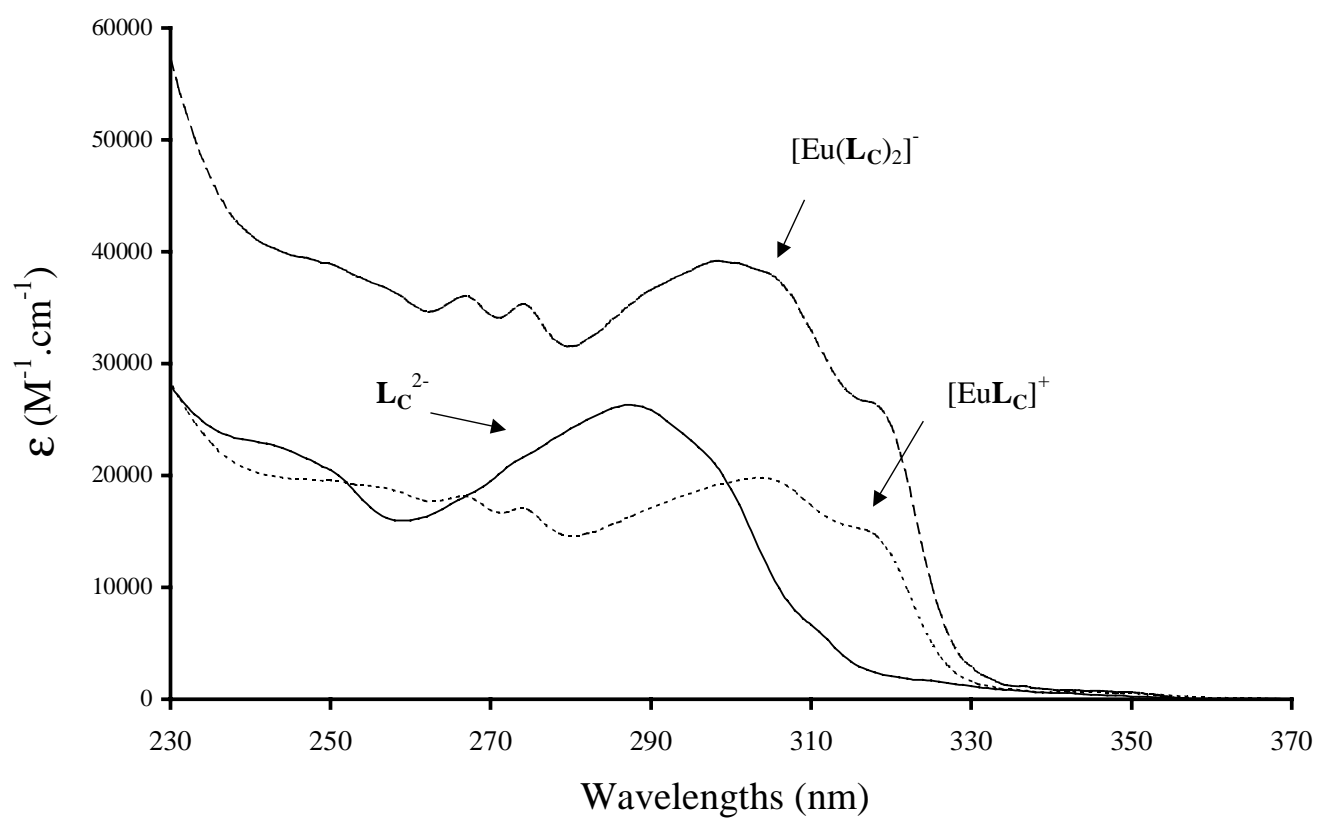

Figure S5 : Calculated UV-Vis absorption spectra of the species formed upon titration of $\mathbf{L}_{\mathbf{C}}$ by $\mathrm{EuCl}_{3} \cdot 6 \mathrm{H}_{2} \mathrm{O}$ in water at $\mathrm{pH}=7.0,0.01 \mathrm{M}$ TRIS/HClO 4 .

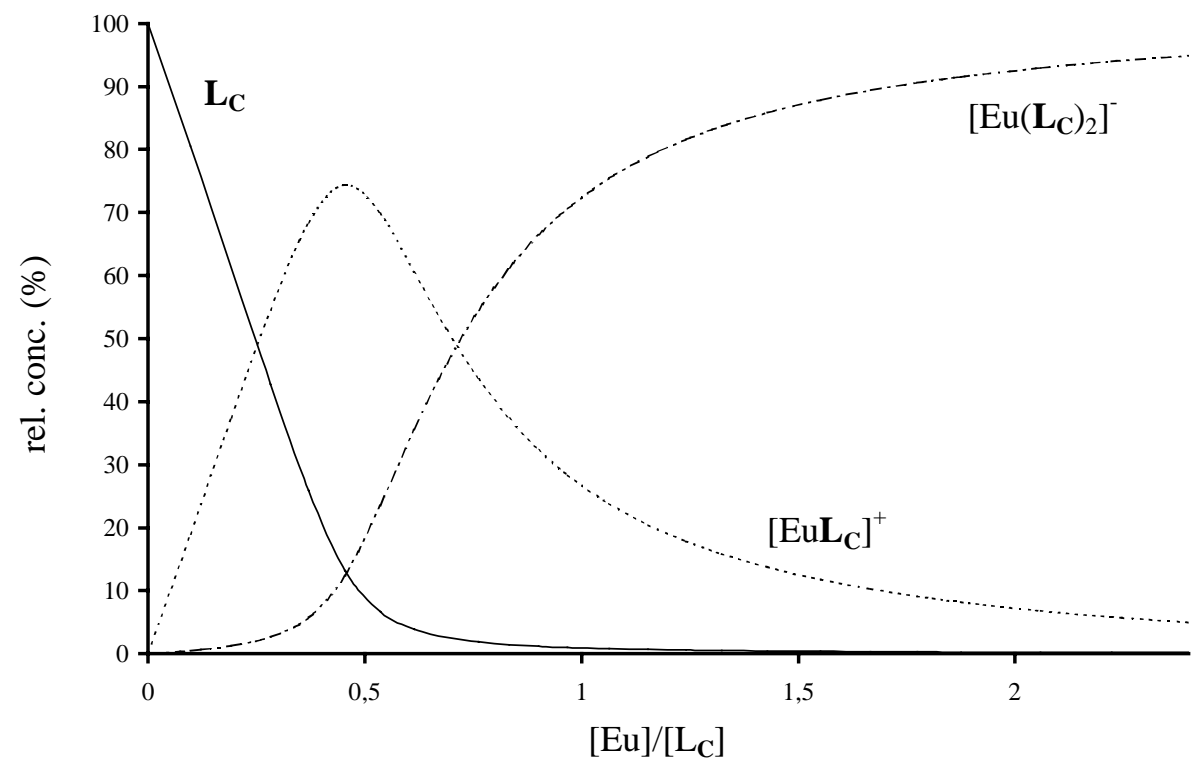

Figure S6 : Evolution of the relative concentrations of the species formed upon titration of $\mathbf{L}_{\mathbf{C}}$ by $\mathrm{EuCl}_{3} \cdot 6 \mathrm{H}_{2} \mathrm{O}$ in water at $\mathrm{pH}=7.0,0.01 \mathrm{M}$ TRIS/ $/ \mathrm{HClO}_{4}$. 


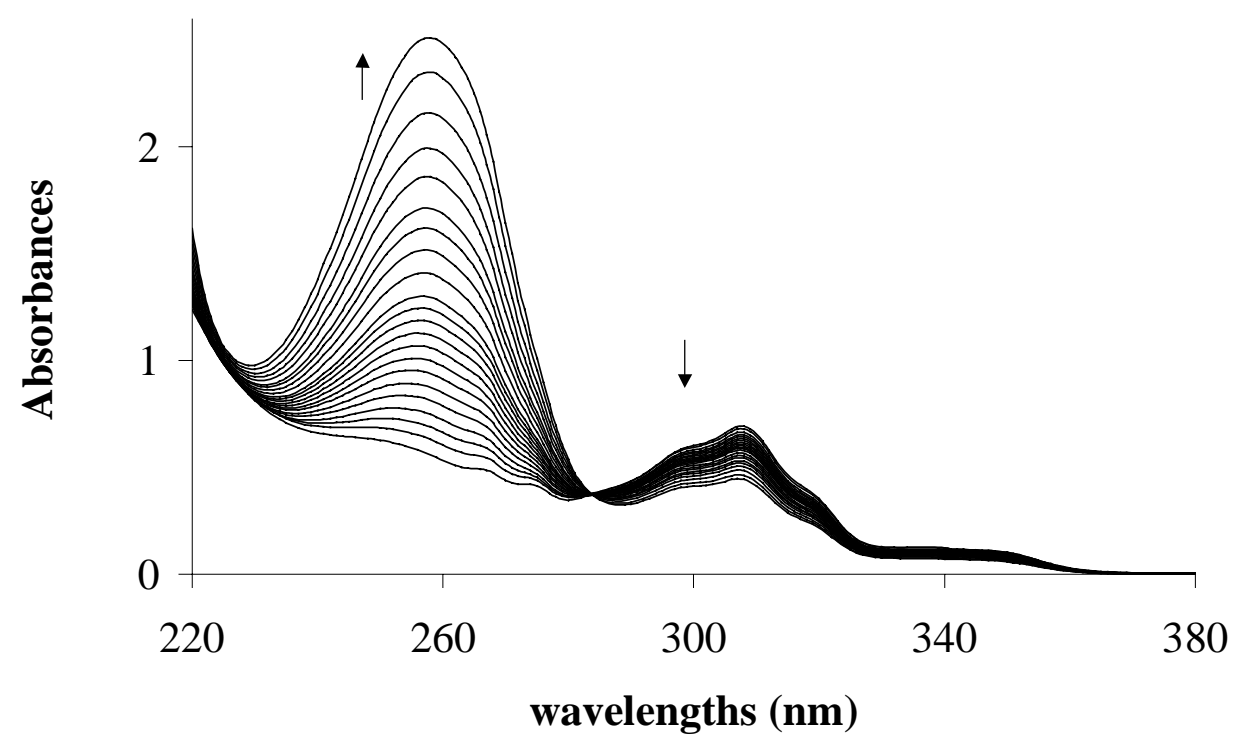

Figure S7 : Evolution of the UV-Vis absorption spectra of a solution of $\left[\mathrm{Eu} \mathbf{L}_{\mathbf{C}}\right]^{+}$upon addition of $\mathrm{ADP}^{3-}$ in water, 0.01 $\mathrm{M}$ TRIS/HCl $\mathrm{pH}=7.0$ (uncorrected for dilution).

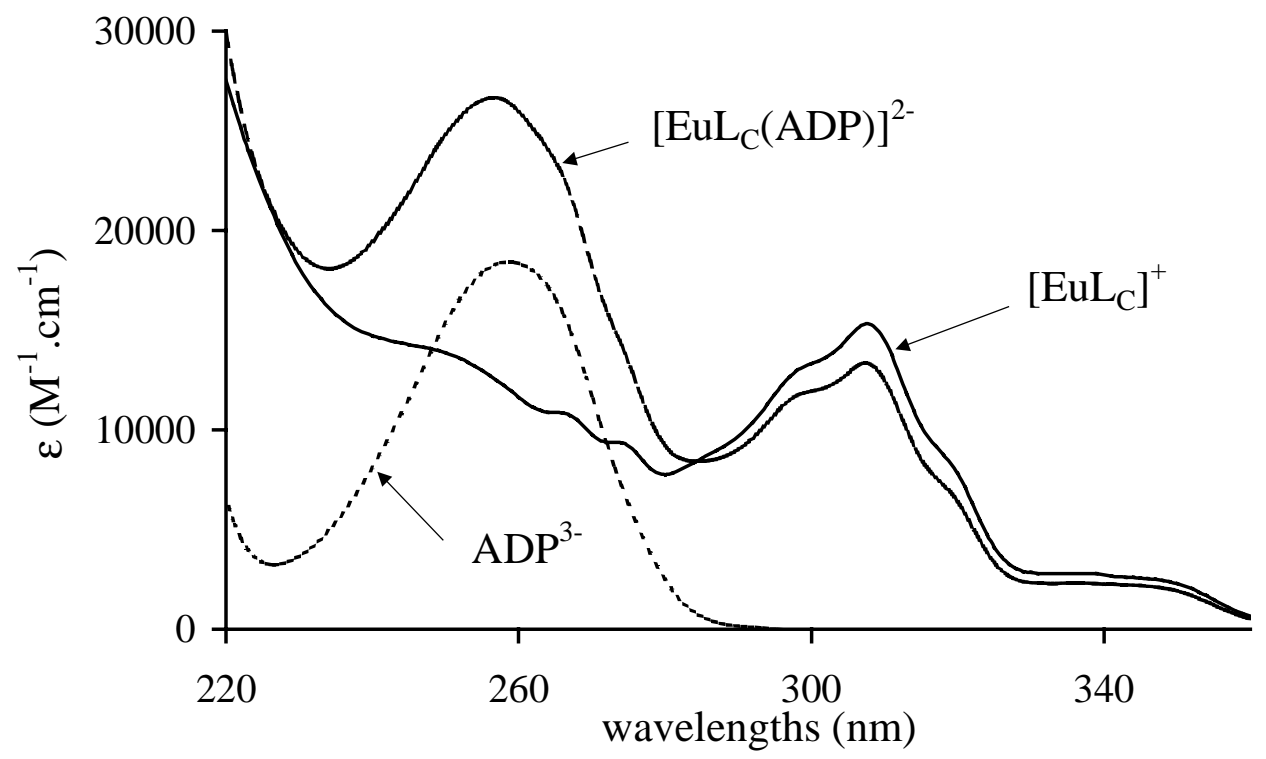

Figure S8 : Calculated UV-Vis absorption spectra of the species formed upon addition of $\mathrm{ADP}^{3-}$ in water, 0.01 M TRIS/HCl, $\mathrm{pH}=7.0$. 


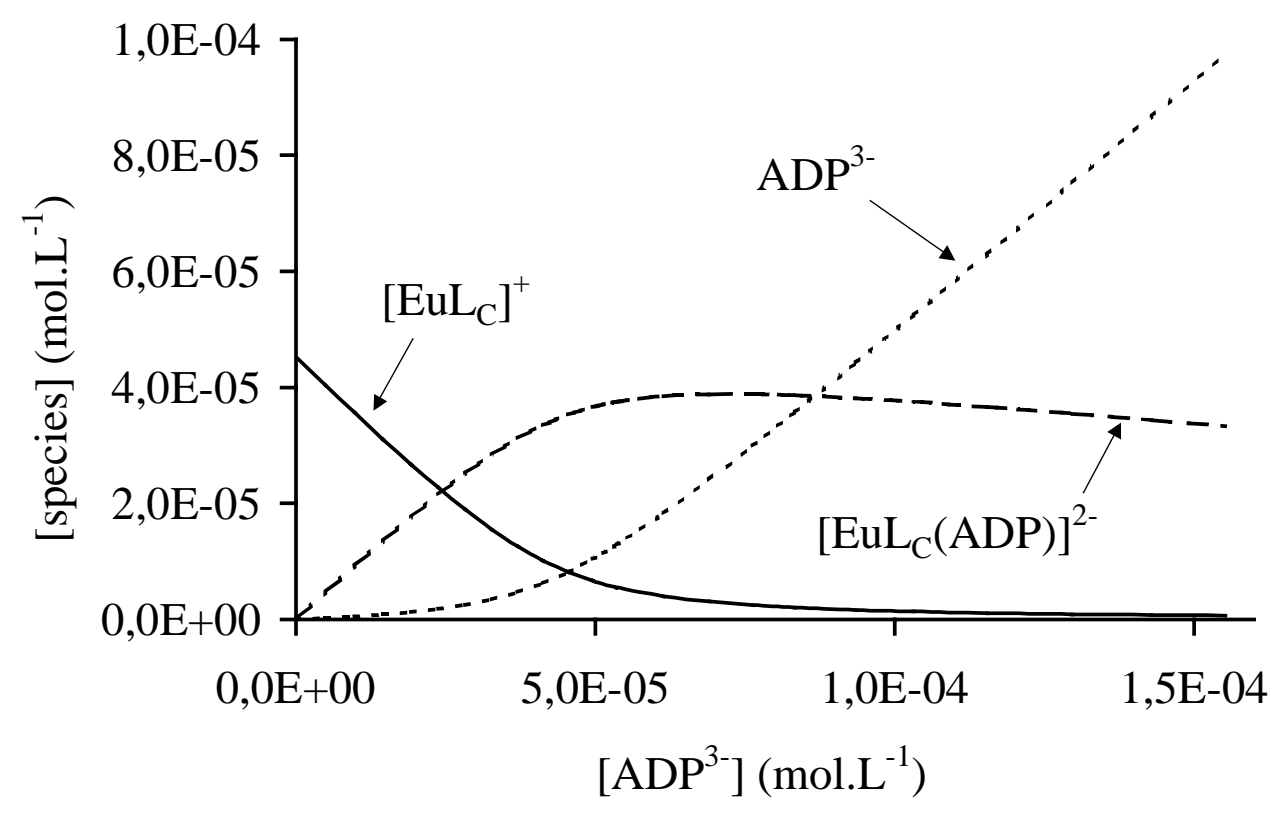

Figure S9 : Evolution of the concentrations of the species formed upon titration of $\left[\mathrm{EuL}_{\mathbf{C}}\right]^{+}$ $\left(5 \times 10^{-5} \mathrm{M}\right)$ by $\mathrm{ADP}^{3-}$ in water at $\mathrm{pH}=7.0,0.01 \mathrm{M}$ TRIS/HCl, $\mathrm{pH}=7.0$.

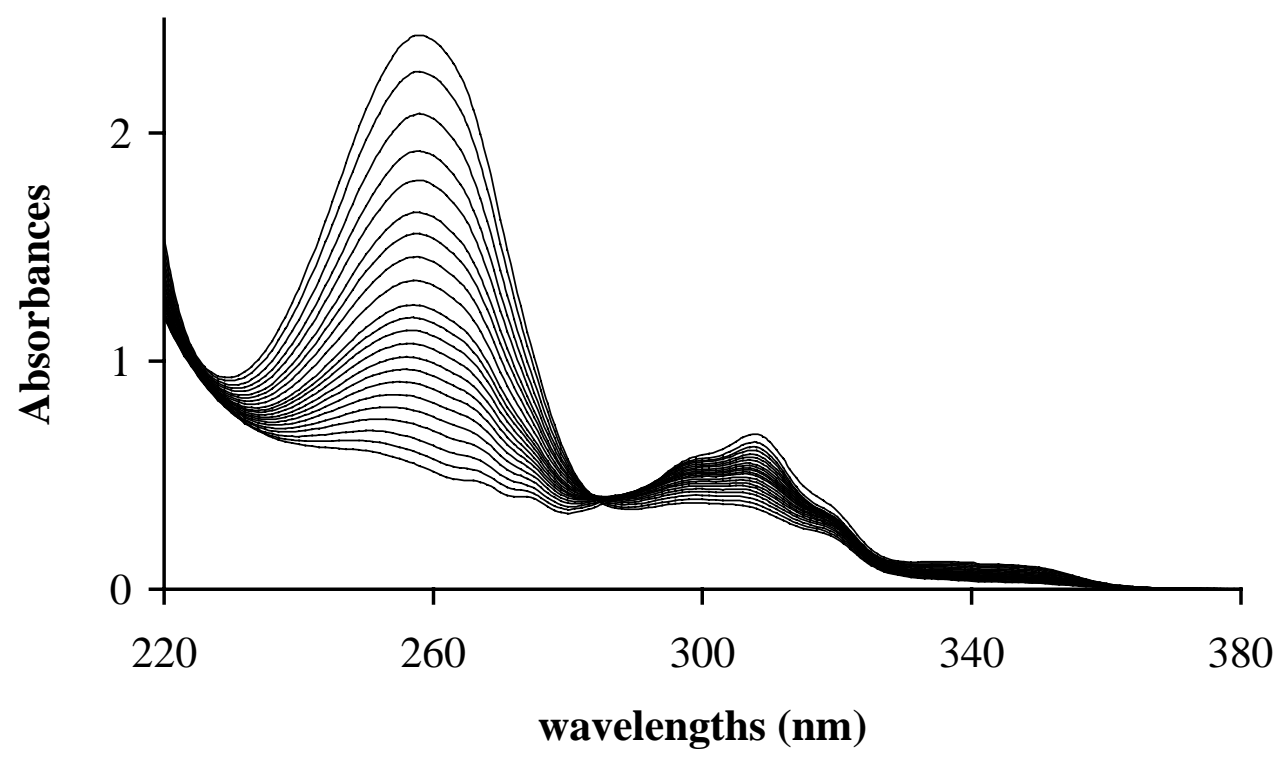

Figure S10 : Evolution of the aborption spectra of a solution of $\left[\mathrm{Eu} \mathbf{L}_{\mathbf{C}}\right]^{+}$upon addition of $\mathrm{ATP}^{3-}$ in water, 0.01 M TRIS/HCl, $\mathrm{pH}=7.0$ (uncorrected for dilution). 


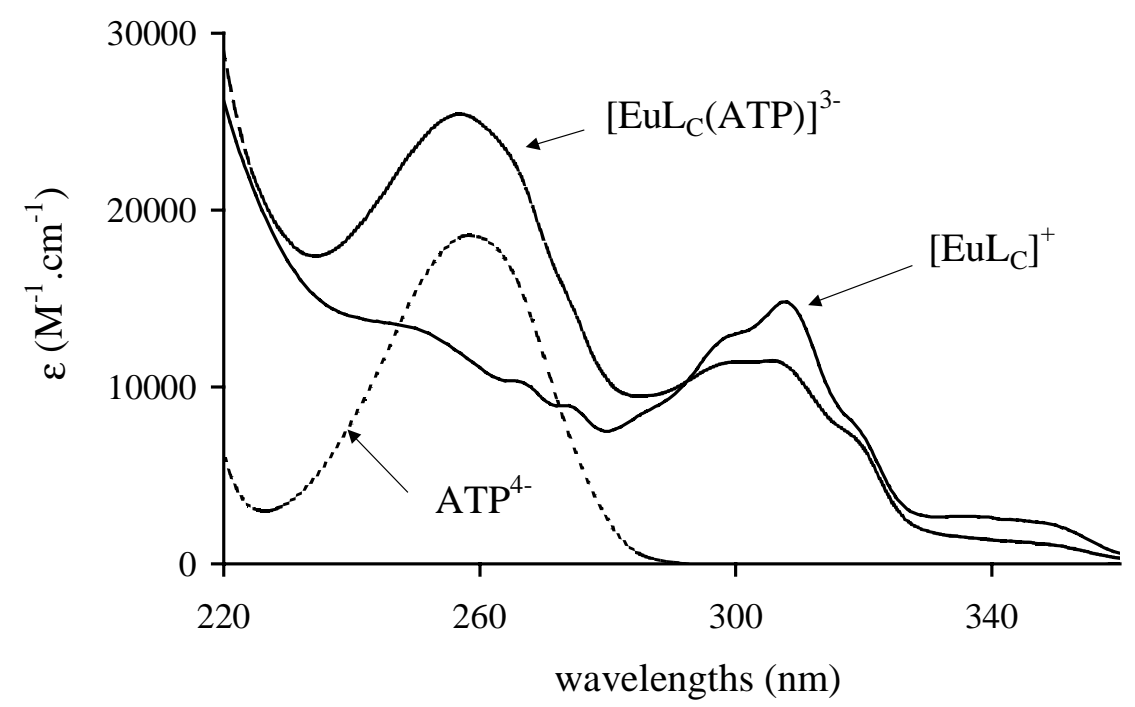

Figure S11 : Calculated UV-Vis absorption spectra of the species formed upon addition of $\mathrm{ATP}^{4-}$ in water, $0.01 \mathrm{M}$ TRIS/HCl, $\mathrm{pH}=7.0$.

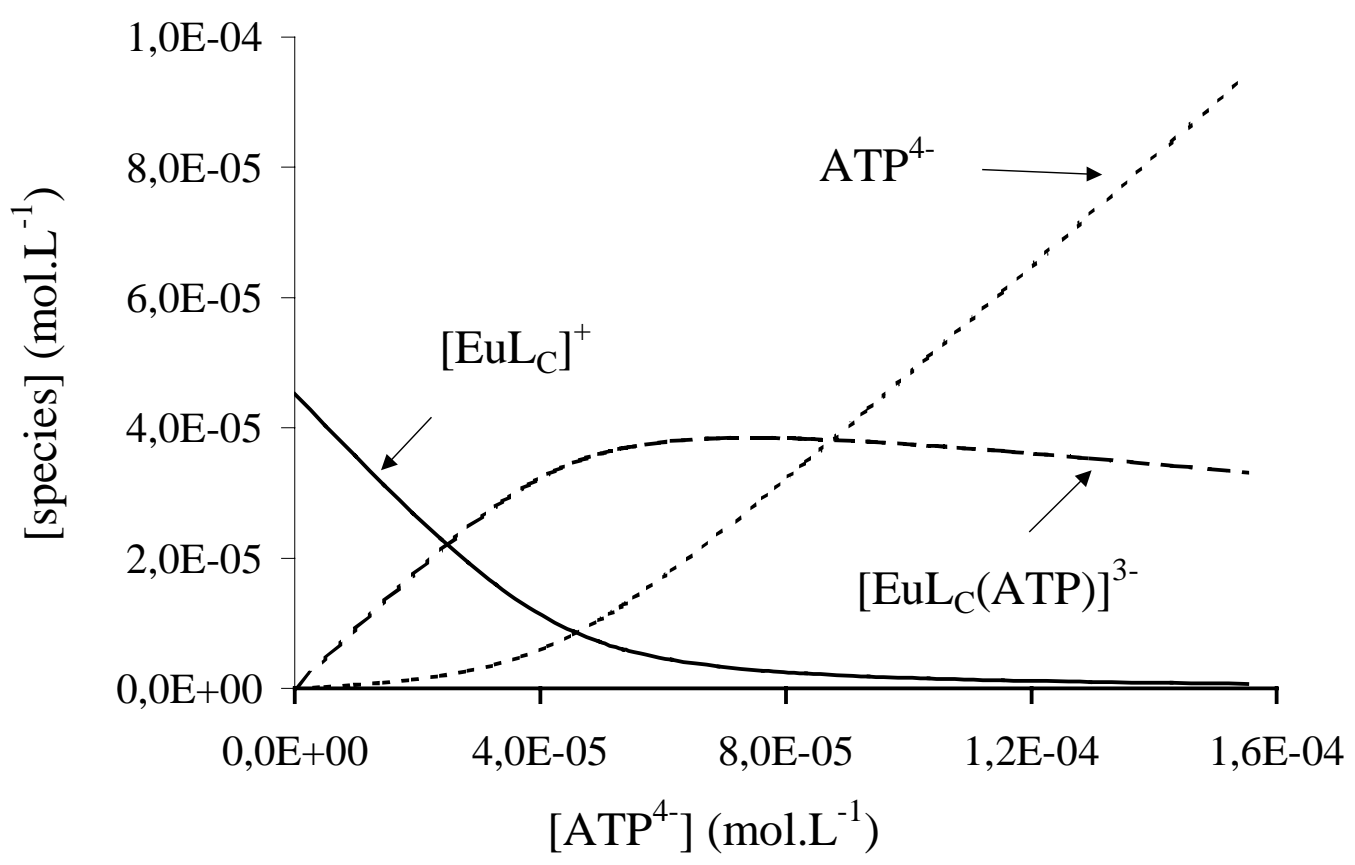

Figure S12 : Evolution of the concentrations of the species formed upon titration of $\left[\mathrm{Eu} \mathbf{L}_{\mathbf{C}}\right]^{+}$ $\left(5 \times 10^{-5} \mathrm{M}\right)$ by $\mathrm{ATP}^{4-}$ in water, $0.01 \mathrm{M}$ TRIS/HCl, $\mathrm{pH}=7.0$. 


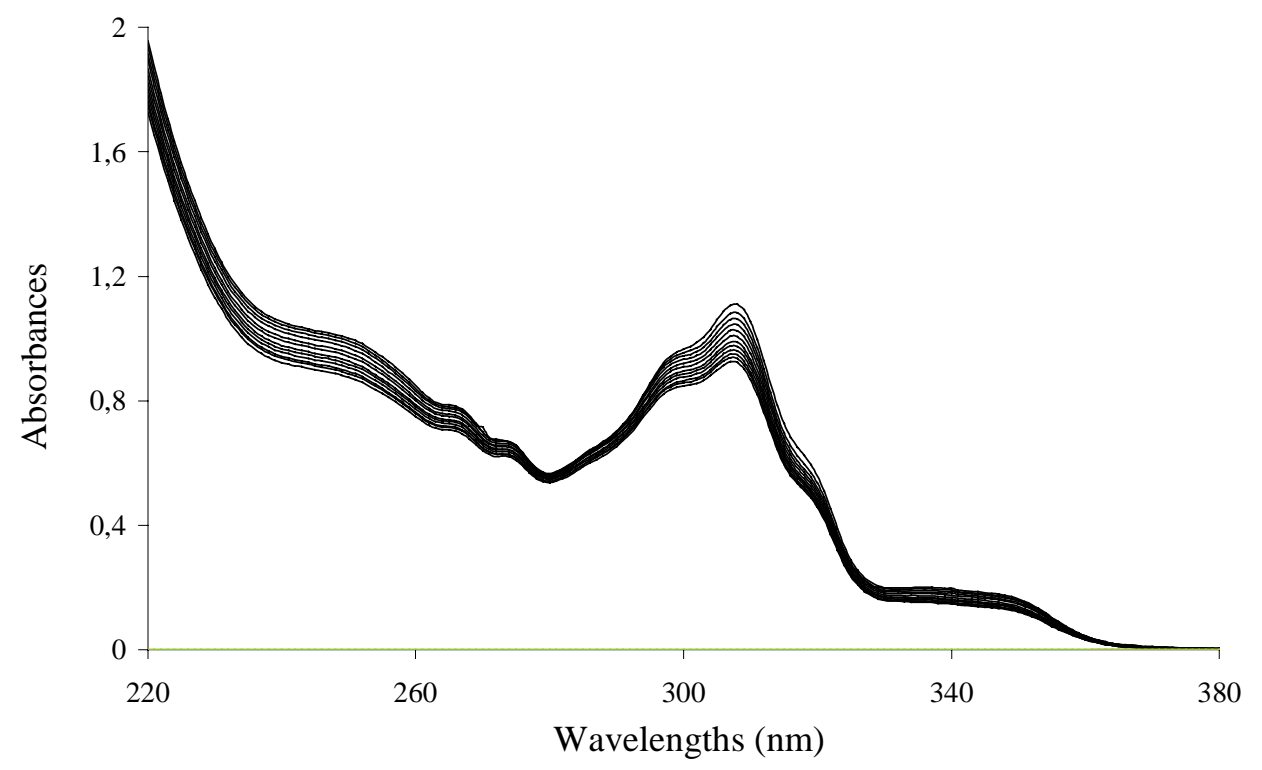

Figure S13 : Evolution of the aborption spectra of a solution of $\left[\mathrm{EuL}_{\mathbf{C}}\right]^{+}$upon addition of $\mathrm{HPO}_{4}{ }^{2-}$ in water, $0.01 \mathrm{M}$ TRIS/HCl, $\mathrm{pH}=7.0$ (uncorrected for dilution).

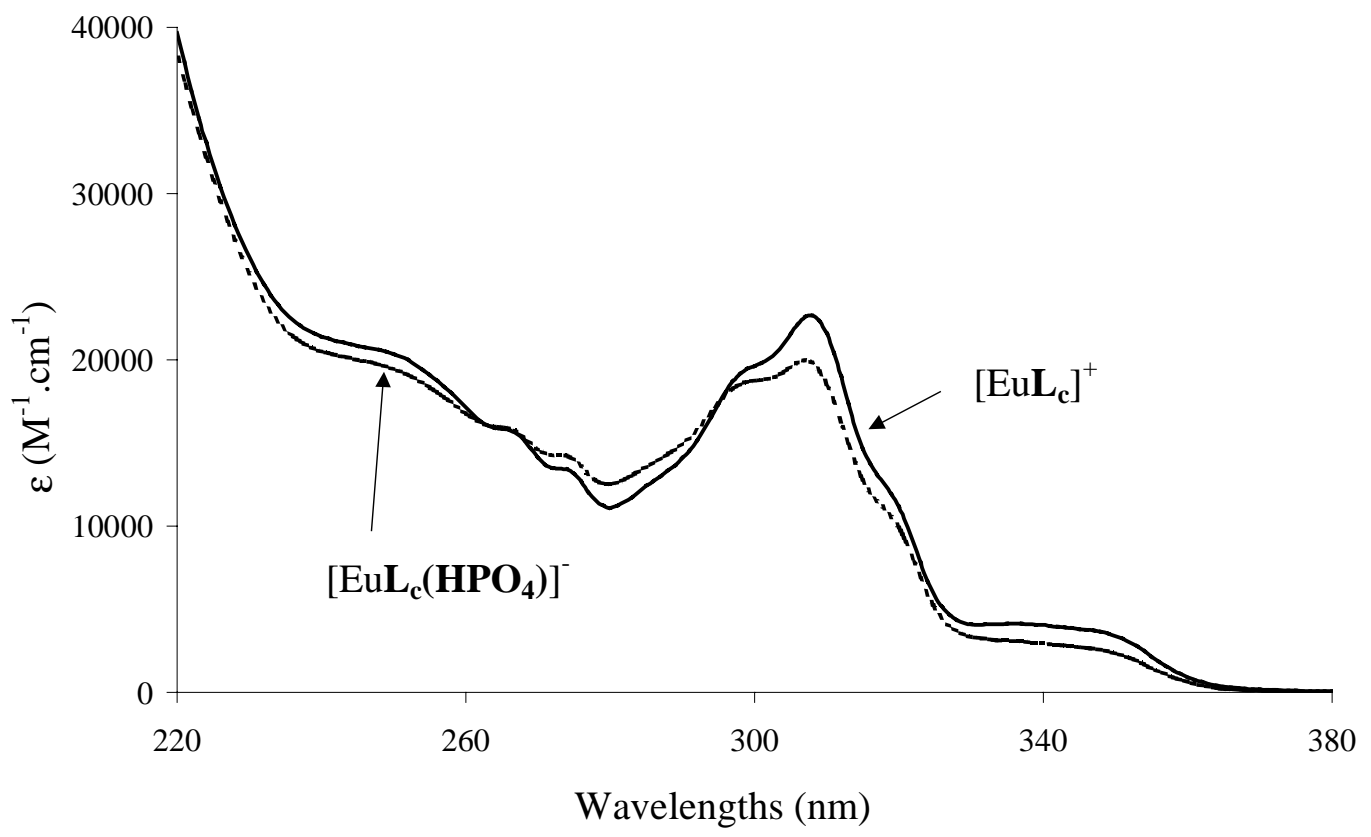

Figure S14 : Calculated UV-Vis absorption spectra of the species formed upon addition of $\mathrm{HPO}_{4}{ }^{2-}$ in water, $0.01 \mathrm{M}$ TRIS/HCl, $\mathrm{pH}=7.0$. 


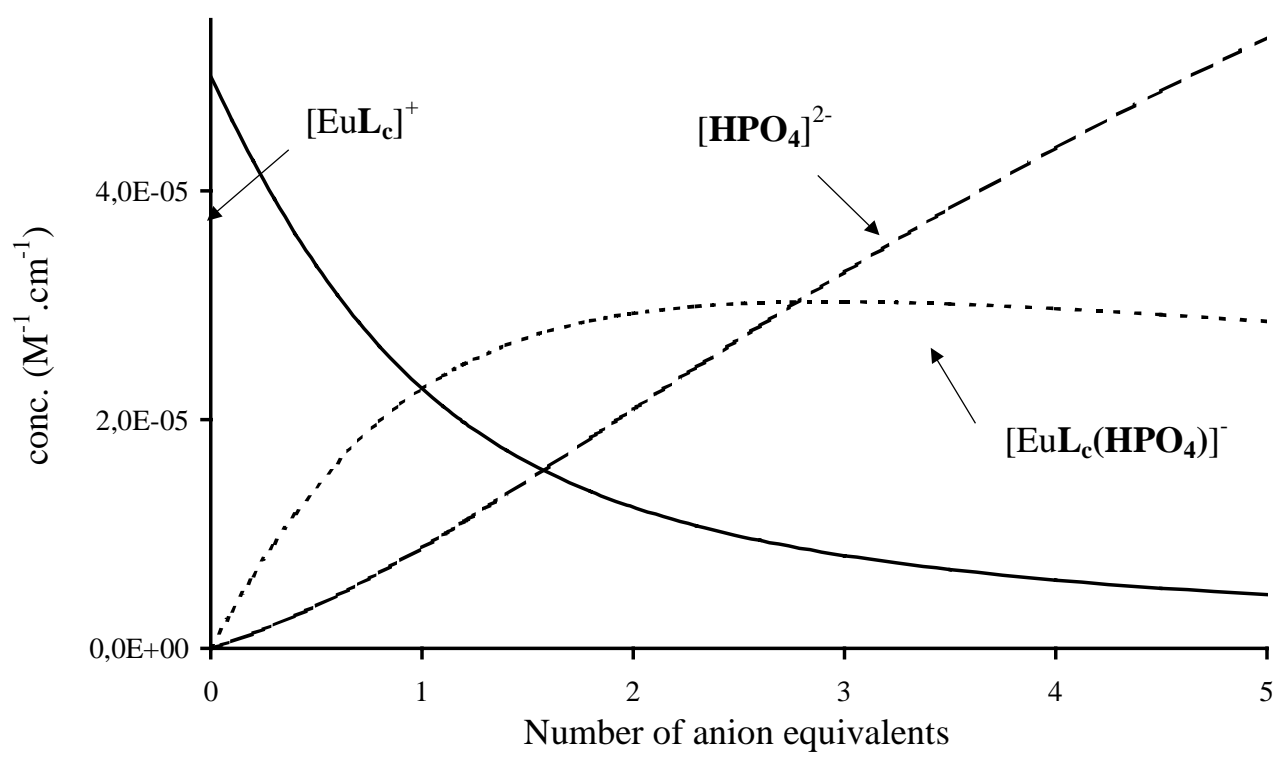

Figure S15 : Evolution of the concentrations of the species formed upon titration of $\left[\mathrm{Eu} \mathbf{L}_{\mathbf{C}}\right]^{+}$ $\left(5 \times 10^{-5} \mathrm{M}\right)$ by $\mathrm{HPO}_{4}{ }^{2-}$ in water, $0.01 \mathrm{M}$ TRIS/HCl, $\mathrm{pH}=7.0$.

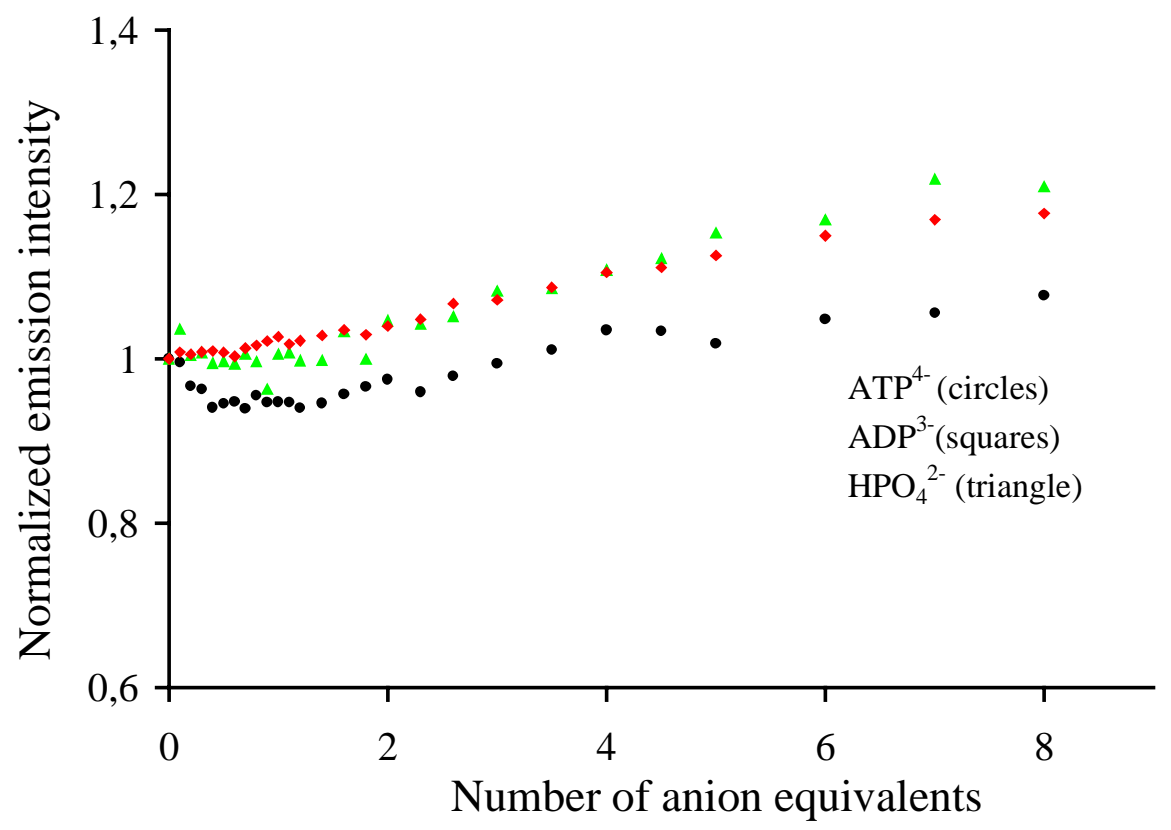


Figure S16 : Evolution of the normalized emission intensity of $\left[\mathrm{Eu} \mathbf{L}_{\mathbf{C}}\right]^{+}\left(\lambda_{\mathrm{exc}}=300 \mathrm{~nm} ; \lambda_{\mathrm{em}}=\right.$ $615 \mathrm{~nm}$ for $\mathrm{HPO}_{4}{ }^{2-}, 600 \mathrm{~nm}$ for the others with a $350 \mathrm{~nm}$ cut-off filter) as a function of added equivalents of anion in water, 0.01 $\mathrm{M}$ TRIS/HCl, $\mathrm{pH}=7.0$.

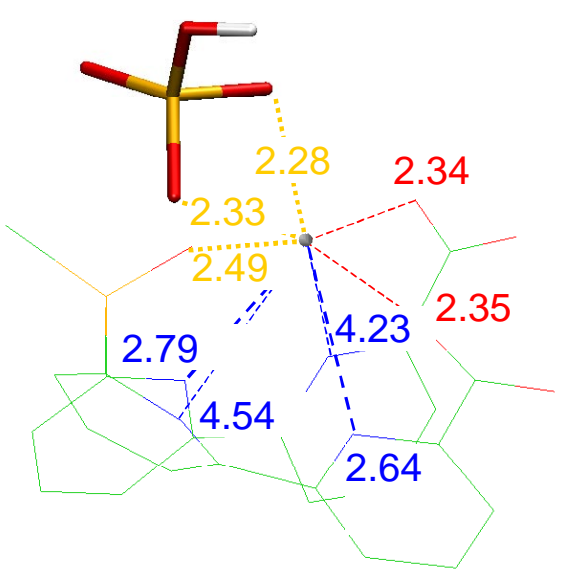

$\mathrm{EuL}_{\mathrm{c}}\left(\mathrm{HPO}_{4}\right)^{-}$

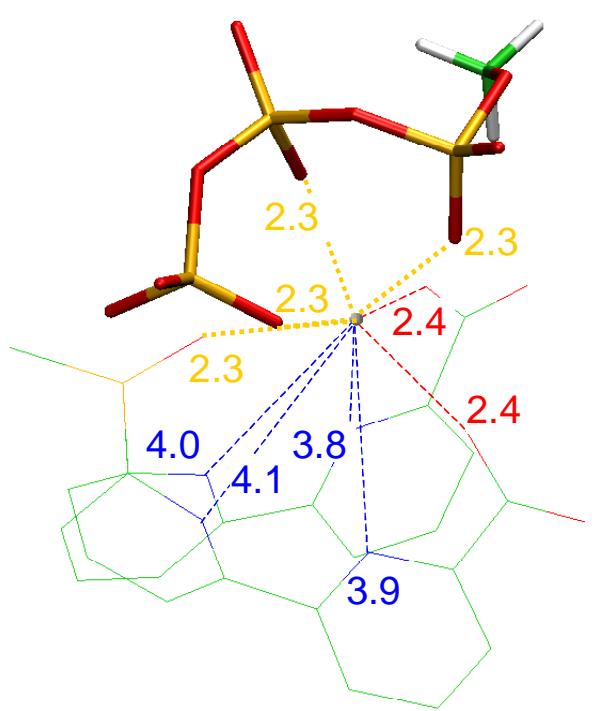

$\operatorname{EuL}_{C}(\mathrm{MeTP})^{3-}$

Figure S17 : Typical bond distances (in $\AA$ ) in the modeled structure of $\left[\mathrm{EuL}_{\mathbf{C}}\left(\mathrm{HPO}_{4}\right)\right]^{-}$and $\left[\operatorname{Eu} \mathbf{L}_{\mathbf{C}}(\mathrm{MeTP})\right]^{3-}$ complexes. 
Table T1 : Evolution of the europium based luminescence lifetime at varying concentration of added $\mathrm{NO}_{3}{ }^{-}$in water, $0.01 \mathrm{M}$ TRIS/HCl, $\mathrm{pH}=7.0$.

\begin{tabular}{|l|c|c|c|c|c|c|c|c|}
\hline equiv. $\mathrm{NO}_{3}^{-}$ & 0 & 1 & 2 & 3 & 4 & 5 & 6 & 7 \\
\hline Luminescence & 743 & 767 & 742 & 792 & 778 & 756 & 748 & 760 \\
lifetimes $(\mu \mathrm{s})$ & & & & & & & & \\
\hline
\end{tabular}

Table T2 : Evolution of the europium based luminescence lifetime at varying concentration of added $\mathrm{ADP}^{3-}$ in water, 0.01 $\mathrm{M}$ TRIS/HCl, $\mathrm{pH}=7.0$.

\begin{tabular}{|l|c|c|c|c|c|c|c|c|}
\hline equiv. $\mathrm{ADP}^{3-}$ & 0 & 1 & 2 & 3 & 4 & 5 & 6 & 7 \\
\hline Luminescence & 808 & 944 & 1009 & 1019 & 1045 & 1017 & 1086 & 1075 \\
lifetimes $(\mu \mathrm{s})$ & & & & & & & & \\
\hline
\end{tabular}

Table T3 : Evolution of the europium based luminescence lifetime at varying concentration of added $\mathrm{ATP}^{4-}$ in water, 0.01 $\mathrm{M}$ TRIS/HCl, $\mathrm{pH}=7.0$.

\begin{tabular}{|l|c|c|c|c|c|c|c|c|}
\hline equiv. ATP & 0 & 1 & 2 & 3 & 4 & 5 & 6 & 7 \\
\hline Luminescence & 739 & 976 & 931 & 1014 & 1003 & 1069 & 1007 & 1001 \\
lifetimes $(\mu \mathrm{s})$ & & & & & & & & \\
\hline
\end{tabular}

Table T4 : Evolution of the europium based luminescence lifetime at varying concentration of added $\mathrm{HPO}_{4}{ }^{2-}$ in water, 0.01 M TRIS/HCl, $\mathrm{pH}=7.0$.

\begin{tabular}{|l|c|c|c|c|c|c|c|c|}
\hline equiv. $\mathrm{HPO}_{4}{ }^{2-}$ & 0 & 1 & 2 & 3 & 4 & 5 & 6 & 7 \\
\hline Luminescence & 780 & 818 & 840 & 865 & 815 & 886 & 865 & 839 \\
lifetimes $(\mu \mathrm{s})$ & & & & & & & & \\
\hline
\end{tabular}

In all cases, luminescence lifetimes were fitted according to single mono-exponential functions. 